Page I - 14

\title{
NON-TARIFF BARRIERS AND FACTORS THAT INFLUENCE THE INDONESIAN COCOA EXPORT TO EUROPE
}

\author{
Raditya Anggoro, Widyastutik \\ Institut Pertanian Bogor \\ raditya.anggoro@gmail.com,widyastutik_ipb@yahoo.com
}

\begin{abstract}
.
The aim of this study are: first, to analyse the competitiveness of Indonesian cocoa in the European Unio market; second, to analyse the competitiveness and the factors that influence the Indonesian cocoa exports to the EU market; third, to calculate the non-tariff barriers imposed by the European Union market for Indonesian cocoa. Methods used are the RCA index and gravity models. The differences between actual and potential trade flows are indicated as non-tariff barriers. Results of the calculation RCA is showed that all destinations of a cocoa export have a high competitiveness $(R C A>I)$ but tend to decrease. Results of the estimate gravity models show the factors influencing the Indonesian cocoa exports are the real per capita GDP of Indonesia and the destination country, CPI of destination countries, the economic distance, exchange rates, and tariff. The result of nontariff barriers indicated that the Netherlands is the state which has the largest non-tariff barriers among the most other EU countries.
\end{abstract}

Keywords: Non-Tariff Barriers; Export; RCA Index; Gravity Models

\begin{abstract}
Abstrak.
Tujuan penelitian ini yaitu: Pertama, menganalisis daya saing kakao Indonesia di pasar Uni Eropa.Kedua, menganalisis daya saing dan faktor-faktor yang mempengaruhi ekspor kakao Indonesia ke pasar Uni Eropa.Ketiga, menghitung hambatan non tarif yang dikenakan oleh pasar Uni Eropa terhadap kakao Indonesia. Metode penelitian yang digunakan adalah indeks RCA dan model gravitasi. Perbedaan antara aliran perdagangan aktual dan potensial diindikasikan sebagai hambatan non-tariff. Hasil perhitungan RCA menunjukan bahwa di semua negara tujuan ekspor utama kakao yaitu Perancis, Belanda, Jerman, Spanyol, United Kingdom, Belgium, Estonia, Bulgaria memiliki daya saing yang tinggi (nilai $R C A>I$ ) namun cenderung mengalami penurunan. Hasil estimasi gravity model menunjukan faktor-faktor yang berpengaruh terhadap ekspor kakao Indonesia yaitu GDP perkapita rill Indonesia dan negara tujuan, IHK negara tujuan, jarak ekonomi, nilai tukar, tarif. Hasil perhitungan hambatan non-tarif menunjukkan bahwa negara Netherlands memiliki hambatan non-tarif terbesar diantar negara Uni Eropa lainnya.
\end{abstract}

Kata Kunci:Hambatan Non-Tarif; Ekspor; Indeks RCA; Model Gravitasi

Received: December 20, 2015; Revised: February 5, 2016; Approved: March 10, 2016 
Non-Tariff Barriers and Factors that influence The Indonesian

Raditya Anggoro, Widyastutik

\section{INTRODUCTION}

Indonesia is known as an agricultural country which is indicated by the number of people who live and work in agricultural sector and a relatively large contribution to the national products. One of the sub-sectors in the agriculture sector is plantation. This sub-sector provides a substantial contribution to the national economy and become very important as a major source of Indonesia foreign exchange. Cocoa is one of the leading commodity plantation sub-sector which has an important role for Indonesia economy especially in providing of job opprtunities, income sources, and Indonesia foreign exchange sources.

Based on FAO (2010), Indonesia is the second largest cocoa producer in the world after Ivory Coast. Table I presents the 10 major producers of cocoa in the world. According to Table I, Indonesia was ranked the second largest cocoa producer about 432,427 per ton pass through Ghana country of 28I,437.

Table I. The Countries of Cocoa Major Producers

\begin{tabular}{clccc}
\hline Ranking & Country & $\begin{array}{c}\text { Quantity } \\
\text { (ton) }\end{array}$ & Value (USD) & $\begin{array}{c}\text { Unit Value } \\
\text { (ton/ I 000 USD) }\end{array}$ \\
\hline I & Ivory Coast & 790912 & 2479240 & 3135 \\
2 & Indonesia & 432427 & 1190740 & 2754 \\
3 & Ghana & 281437 & 847395 & 3011 \\
4 & Nigeria & 226634 & 659886 & 2912 \\
5 & Cameroon & 193881 & 608847 & 3140 \\
6 & Netherlands & 167081 & 571647 & 3421 \\
7 & Ecuador & 116318 & 350199 & 3011 \\
8 & Belgium & 82614 & 293634 & 3554 \\
9 & Togo & 82100 & 197000 & 2400 \\
10 & Papua Nugini & 57764 & 176692 & 3059 \\
\hline
\end{tabular}

Source: Food and Agriculture Organization (FAO), 2010

However, Indonesian cocoa export is fluctuated. In 2003, Indonesian cocoa export reached 623,934 USD and declined to 549,348 USD in 2004. The increase in exports began from 2007 to 2010 . It reached $\$ 1,643,649$ whilst between $201 \mathrm{I}$ and 2012 , has decreased up to $\$ 1,053,447$.

One of the main Indonesian cocoa market is the European Union (EU)market, in 2004, although Indonesia was the 2nd largest cocoa producer in the world and has an advantage because the chemical character of chocolate which produced from Indonesia cocoa beans was not owned by other countries cocoa, 
but in terms of exports to the EU market, Indonesia only occupy 6th position i.e.2.46\% market share only orbelow its production capacity (Widyastutik and Arianti, 2013). In addition to the tariff where Indonesia competitors such as Ivory Coast, Ghana, Nigeria and Cameroon are incorporated in the Africa, Caribbean, Pacific (ACP) Countries preference custom duties preferences to Europe, the low of Indonesia market share the EU market is closely related to EU standards and quality policy of cocoa exports, the fermentation requirements (Indonesian Mission, 2010). In the EU market, quality of Indonesian cocoa is considered low because it contains high acidity, low precursor compound flavour, and low levels of fat, so the price of Indonesian cocoa always gets a quite high rebate, about 15\% from global cocoa price average (Ministry of Industry, 2005).

The EU market which the main Indonesia export destinations of cocoa has a policy that exporters who enter the EU market should pay more attention to the various requirements set by trading partners and EU governments. These requirements includes quality standards usually associated with environmental, health, security, labour and business ethics, and regulations that are adopted by the European Union applied for all countriesand becomes serious problems for exporters, especially Indonesia.

The issue of Indonesian cocoa non-tariff barrier swill affect the competitiveness of Indonesian cocoa inEU market. Therefore, the research questionsare as follows: How Indonesian cocoa competitiveness in major exports destination countries (the EU)? What factors are affecting the Indonesian cocoa exports to the EU market? How greatdoes the EU market to Indonesian cocoa exports impose the non-tariff barriers?

This study analyses the competitiveness, factors that affect Indonesia cocoa export to eight EU country marketsas well as measuring non-tariff barriers. Indonesia's main export destination countries in EU markets are France, Netherlands, Germany, Spain, United Kingdom, Belgium, Estonia, and Bulgaria. The period was used from 2001 to 2012 and classification used is the Harmonized System (HS) 18 for cocoa (cocoa and cocoa preparations). 
Non-Tariff Barriers and Factors that influence The Indonesian

Raditya Anggoro, Widyastutik

\section{METHOD}

This study uses secondary data as well as panel data is 8 major destinations of Indonesian cocoa exports. Data and sources that are required in gravity models can be seen in Table 2 .

Table 2. Data and Sources

\begin{tabular}{clc}
\hline No & \multicolumn{1}{c}{ Data } & Sources \\
\hline I & Export Value & Trade Map \\
2 & Indonesia GDP per Capita & World Bank \\
3 & Destination Countries GDP per Capita & World Bank \\
4 & Distance & CEPII \\
5 & Consumer Price Index & IMF \\
6 & Exchange Rate & UNCTAD \\
7 & Tariff & WITS \\
\hline
\end{tabular}

In this study, the RCA is defined to explain the comparative advantage of Indonesian cocoa exports in the total exports of Indonesian commodities. The RCA formulas used in this calculation is as follows:

$$
R C A_{I J}=\frac{X_{i j} / X_{i t}}{X_{j} / X_{t}}
$$

Where:

$$
\begin{array}{ll}
\text { RCA }_{\mathrm{ij}} & =\text { Competitiveness value of Indonesian Cocoa } \\
X_{i j} & =\text { Export value of Indonesian Cocoa } \\
X_{i t} & =\text { Total Export of Indonesia } \\
X_{i} & =\text { Export of World Cocoa } \\
X_{t} & =\text { Export of World Products }
\end{array}
$$

Competitiveness value of a commodity that resulted from RCA method has two alternative interpretations such as: First, RCA value $>$ I, then a country has a comparative advantage over the average world so that it can be interpreted that commodity has strong competitiveness. Second, Value RCA $<\mathrm{I}$, then a country has a comparative advantage under the average world so that it can be interpreted this commodity has low competitiveness. Panel data model with gravity approach in this study are as follows:

$$
X_{I J}=A_{i} \frac{Y i^{a 1} Y j^{a 2}}{\text { Dist } i j^{a 3}}
$$


Where:

$\mathrm{X}_{\mathrm{ij}} \quad=$ Export Volume (ton)

$\mathrm{A}_{\mathrm{i}} \quad=$ Constant

$Y_{\mathrm{i}} \quad=$ GDP of Indonesia (US\$)

$Y_{j}=$ GDP of Export Destination (US\$)

Distij = Distance

$\alpha_{1}, \alpha_{2}, \alpha_{3}=$ Estimation Parameter

In this study, the panel data model with the approach of the gravity model using primary variable GDP per capita rill, the distance, the exchange rate Indonesia to export destinations, the consumer price index, and rates. By doing transformation logarithms, the obtained linear equation as follows:

$\log X_{i j}=c+\log$ GDPCit $X_{1}+\log$ GDPCjt $X_{2}+\log$ Erijt $X_{3}+\log$ Dijt $_{4}+\log$ Qpijt $X_{5}$

$$
+\log C P l j t X_{6}+\text { eij }
$$

where:

$\mathrm{X}_{\mathrm{ij}} \quad=$ Export Value (percent)

$\mathrm{GDPC}_{\mathrm{it}} \quad=$ Indonesia GDP per capita (percent)

$\mathrm{GDPC}_{\mathrm{jt}}=$ Export Destinations GDP per capita (percent)

$\mathrm{Er}_{\mathrm{ijt}} \quad=$ Real Exchange Rate (percent)

$D_{\mathrm{ijt}} \quad=$ Economic Distance (percent)

$\mathrm{QP}_{\mathrm{ijt}} \quad=$ Tariff (percent)

$\mathrm{CPI}_{\mathrm{jt}} \quad=$ Export Destination Consumer Price Index (percent)

Economic distance is obtained based on Karlinda (20I2) calculation as follows:

$$
J E_{i j t}=J G_{i j} \times \frac{\sum \text { Total } G D P_{j}}{G D P_{j t}}
$$

Information:

$\mathrm{JE}_{\mathrm{ijt}} \quad=$ Economic Distance from $\mathrm{i}$ country to $\mathrm{j}$ country in $\mathrm{t}$ year

$\mathrm{JG}_{\mathrm{ij}} \quad=$ Geographical Distance from i country to $\mathrm{j}$ country

$\sum$ Total $G D P_{j}=$ GDP Total in j country

$\mathrm{GDP}_{\mathrm{it}} \quad=$ GDP on $\mathrm{j}$ country in $\mathrm{t}$ year 
Non-Tariff Barriers and Factors that influence The Indonesian

Raditya Anggoro, Widyastutik

After all the parameters are estimated, potential trade flows can be obtained by substituting all data into a gravity estimate equation. The fitted trade flows of gravity equation are specified as a potential trade flows. The differences between actual and potential trade flows indicate that non-tariff barrier and normalized with free trade benchmark. Free trade benchmark country on this research is France. The formula to measure non-tariff barriers is based on Park (2002), Francois et al (2003), Chalagan and Uprasen (2008) and Walsh (2008) as follows:

$$
T_{i j}=\left(\frac{\text { Xjak } / \text { Xjpot }}{\text { Xbak } / \text { Xbpot }}\right)^{-1 / e}
$$

Information:

$\mathrm{T}_{\mathrm{ij}} \quad=$ non-tariff barriers for $\mathrm{i}$ commodity

$\mathrm{X}_{\text {jak }}=$ actual export volume on each export destination country

$\mathrm{X}_{\mathrm{jpot}}=$ potential export volume on each export destination country

$\mathrm{X}_{\text {bak }}=$ actual export volume Indonesia cocoa trade benchmark country

$\mathrm{X}_{\text {bpot }}=$ potential export volume Indonesia cocoa trade benchmark country

e $\quad=$ elasticity of substitution Indonesia cocoa which is derived based on

Permani(20II) i.e. 0.62 .

\section{DISCUSSION}

Indonesian cocoa has a fluctuating competitiveness in $8 \mathrm{EU}$ countries in the last five years. In 2007, Indonesian cocoa hada low competitiveness in the United Kingdom with RCA < I by 0.4 while in other countries, France, Netherlands, Germany, Spain, United Kingdom, Belgium, Estonia, Bulgaria in 2007 have a high competitiveness (RCA> I). Table 3 shows the development of Indonesian cocoa competitiveness in EU countries.

In 2007, Indonesian cocoa had the highest competitiveness index in France. It number declined from 2008 to 2012, representing 4.88. Likewise, Indonesian cocoa competitiveness in Estonia decreased sharply starting from 2008 to 2012 that is equal to 0.02 . However, Indonesian cocoa competitiveness index decreased significantly to $3.3 \mathrm{I}$ in the United Kingdom over five years period. 
Table 3. Indonesian Cocoa Competitiveness Index in EU 2007 - 2012

\begin{tabular}{lrrrrrr}
\hline \multirow{2}{*}{ Countries } & \multicolumn{7}{c}{ RCA } \\
\cline { 2 - 7 } & $\mathbf{2 0 0 7}$ & $\mathbf{2 0 0 8}$ & $\mathbf{2 0 0 9}$ & $\mathbf{2 0 1 0}$ & $\mathbf{2 0 I I}$ & $\mathbf{2 0 1 2}$ \\
\hline France & $\mathrm{II} .86$ & $\mathrm{I} 4.28$ & 12.94 & 5.50 & 4.96 & 4.88 \\
Netherlands & 3.06 & 2.65 & $\mathrm{I} .43$ & $\mathrm{I} .19$ & 0.77 & 0.38 \\
Germany & $\mathrm{I} .63$ & $\mathrm{I} .54$ & 3.03 & 5.59 & 2.92 & 5.27 \\
Spain & $\mathrm{I} .35$ & 3.18 & $\mathrm{I} .38$ & 0.00 & 5.69 & 3.16 \\
United Kingdom & 0.40 & 0.25 & 1.30 & $\mathrm{I} .54$ & 3.16 & $3.3 \mathrm{I}$ \\
Belgium & 5.45 & 0.99 & 0.38 & $\mathrm{I} .40$ & 0.84 & 0.52 \\
Estonia & $14.0 \mathrm{I}$ & 12.50 & 7.24 & 3.04 & 9.43 & 0.02 \\
Bulgaria & $\mathrm{I} .16$ & 0.55 & 0.90 & $\mathrm{I} .14$ & 1.59 & $3.1 \mathrm{I}$ \\
\hline
\end{tabular}

The best model estimating the factors that influence Indonesian cocoa exports carried out by panel data on a fixed effect model with weighting SUR (Seemingly Unrelated regressions) in cross section. According to table 4, estimation result model showed that each variable has a probability value less than $\alpha=0.10$. This means that all variables are significant or affect to Indonesian cocoa exports. Probability of statistic $F$ on that model has a 0.000000 value less than $\alpha=0.10$, it can be concluded that the variables used in the model significantly affect to Indonesian cocoa exports volume assuming ceteris paribus.

R-squared value obtained 0.885642 , indicating that the overall model can be explained by the variables in the model of $88.56 \%$, while $11.43 \%$ the rest is explained by other variables outside the model. Estimation model for the factors that affect cocoa exports using fixed effect model weighted GLS cross section SUR (Seemingly Unrelated regressions). By performing the weighting, heteros cedasticity problems in the model can be overcome.

On normality assumption test, Indonesian cocoa exports estimation model, the result showed that the probability of Jarque Bera is 1.55 , representing more than $10 \%$. This means that the estimation model has a normal distribution residual. Durbin Watson estimation score is 1.95 . This value is in the range du (1.8265) and 4-du (2.1735), meaning that there is no autocorrelation problem in the estimation model of Indonesian cocoa exports. 
Non-Tariff Barriers and Factors that influence The Indonesian

Raditya Anggoro, Widyastutik

Table 4. Estimation Result

\begin{tabular}{|c|c|c|c|}
\hline Variabel & Koefisien & t-statistic & Probabilitas \\
\hline GDPCi & 1.610019 & 2.393956 & 0.0189 \\
\hline GDPCj & -3.38535 & -3755487 & 0.0003 \\
\hline DISTIJEKO & 0.267978 & $\mathrm{I} .672753$ & 0.0982 \\
\hline ERIJ & 1.961795 & 4.004433 & 0.0001 \\
\hline CPIJ & $-0.0154 \mid$ & -3.91699 & 0.0002 \\
\hline Tarif & -0.02845 & -1.797786 & 0.0759 \\
\hline C & 53.41629 & 4.60829 & 0.0000 \\
\hline \multicolumn{4}{|c|}{ Weighted Statistic } \\
\hline \multirow[t]{2}{*}{ R-squared } & 0.885642 & Sum square resid & 94,12734 \\
\hline & \multicolumn{3}{|c|}{ Durbin-Watson } \\
\hline Prob (F-statistic) & 0.000000 & stat & 1.957036 \\
\hline \multicolumn{4}{|c|}{ Unweighted Statistic } \\
\hline \multicolumn{4}{|c|}{ Durbin-Watson } \\
\hline R-squared & 0.690443 & stat & I.6488I I \\
\hline Sum square resid & 76.48645 & & \\
\hline
\end{tabular}

The real Indonesia GDP per capita variable estimation result indicates that has a positive significant effect on Indonesian cocoa exports. This means that any increase in GDP per capita by 1\%, the Indonesian cocoa exports to major export destination countries will increase by $1.6 \%$, assuming ceteris paribus. In approaching gravity model, the real GDP indicates that the size of country economy. For exporting country, real GDP showed the country's production capacity (Yuniarti, 2007).

In the export equation, destination country GDP real per capita shows that the purchasing power of the country is at once the country's ability to produce. The result indicates that the destination country GDP real per capita has a negative significant effect on Indonesian cocoa exports to Indonesian cocoa main export destinations. Hence, the increase in destination country GDP per capita by $1 \%$, it will cause decreasing on Indonesian cocoa market share of $3.38 \%$, assuming ceteris paribus. According to Singagerda (20I3), the greater GDP per capita the greater 
size of country economy. The high GDP shows their ability to increase production and meet the society needs, so when the countries increase its production, the state tends to reduce imports and would bring down Indonesia exports to destination countries.

Distance variable between Indonesian economy and the Indonesian cocoa main export destination country has a positive effect on Indonesian cocoa exports. Thus, an increase of $1 \%$ of economy will improve Indonesian cocoa exports in the EU market of $0.26 \%$ percent. Marlina (2013) said that the distance in the gravity model is a proxy from transportation costs. The result form Behar and Venables (2010) indicated that technological advances in transport has encouraged an increase in the quality (speed and reliability) of transportation so that costs will be lower, which is stimulated the trade. Hence, distance is no longer a problem in doing export of cocoa, so that exports increased.

The estimation results of the model indicated that the consumer price index variable of destination country has a negative significant influence on Indonesian cocoa exports. It means thatthe increasing of consumer price index by $1 \%$, Indonesian cocoa exports declined by $0.01 \%$, assuming ceteris paribus. The consumer price index of destination country is a proxy of the prices prevailing in a country that can influence consumer purchasing power (Mankiw 2007). Exchange rate variable has a positive significant influence to cocoa exports. Hence, any increase in the amount of exchange rate of $1 \%$ would increase current surplus account about $1.96 \%$, by the ceteris paribus assumption. This is due to the rupiah depreciation which decrease the cocoa price cocoa that was produced by Indonesia. This decline will cause the demand for goods and services by overseas increased so that the value of cocoa exports also rose.

On the other hand, an import tariff policyis imposed by export destination country that related to Indonesian cocoa which had a negative effect to Indonesian cocoa export. Everyarise of tariff to $1 \%$, it will drop Indonesian cocoa exports by $0.02 \%$, assuming ceteris paribus while import tariffs will increase Indonesian cocoa price in the importing country. This is supported by Latiefah et al (2013) that related to customs tariffs, causing a decrease in the amount of imports that meant a decrease in the number of export for the export countries. 
Non-Tariff Barriers and Factors that influence The Indonesian

Raditya Anggoro, Widyastutik

Calculation of Non-Tariff Barriers Value of Indonesian Cocoa in Each EU Country

Non-tariff barriers become an important issue in international trade. Tariff barrierswere lowered from year to year which based on the agreement of each country so that there is an incentive to apply non-tariff barriers. The application of non-tariff barriers is indicated to be one cause of Indonesian cocoa exports declining. Some regulations that related to cocoa in Europe according to Indonesia Mission (2010) are: (I) European Community Regulations (EC) No. 178/2002 that deals with the general principles and requirements of food. This regulation is not in the form of the Act but usually clicking belt across the EU member states. (2) Directive 93/43/EEC stipulates that every company engaged in the food which carrying out any activities must comply with food safety and ensure that each procedures should be complied with food security defined such as: Hazard Analysis Critical Control Point (HACCP) system. Consequently, the EU food industry will not do a business with a company that does not implement HACCP provisions. This regulation increases the cost, beside the risk of rejection due to get away from regulatory agencies. (3) Council Regulation (EEC) 2029/9I such as: EU regulations for organic food production and labelling. (4) The Amendment of Council regulation No. 1804/1999 regarding organic and genetically modification provision that requires that Genetically Modified Organisms (GMOs) and derivative products cannot use labels like other organic products. (5) Council Regulation (EC) No II54/98 that manage the granting of special incentives and agriculture products industrial from third countries coming into the EU market if it has been carrying out of human rights and protecting the environment. Besides the EU, other parties such as consumer associations also give serious attention to this problem. Several consumer associations in the EU are giving serious attention to the environmental and social problem, apropos Scandinavia, Germany, the Netherlands and the United Kingdom. (6) Regulation (EC) No 850/2004 regulates the prohibition of producing or entering or using the product with persistent organic pollutants into EU markets. (7) Directive 94/62/EC sets waste packaging, the packaging should be recyclable, do not contain harmful substances such as heavy metals, the packaging must be safe, cleanand accepted by society. (8) Directive 200I/95/EC that general food safety; consumers should be informed risks that may occur if consuming such products.(9) 
Directive 2000/36/EC regulates the cocoa and chocolate products for human consumption.

Although EU implements regulations that apply to all members, its applications in the field are applied differently in each member. This is evidenced by the variation of non-tariff barriers value in all EU members. Table 4.2presents the amount of non-tariff barriers imposed on each of country destinations for Indonesia exporting cocoa to the EU. Non-tariff barriers value for Indonesian cocoa is imposed by the Netherlands with an average of non-tariff barriers by $312.01 \%$. That value becomes the largest non-tariff barriers value among 8 Indonesian cocoa major export destinations. The highnon-tariff barriers that imposed by the Netherlands would affect to Indonesian cocoa products export. One of export requirements that are difficult fulfilled Indonesian exporters are the requirements set by the Industrial chocolate and foods containing chocolate that cocoa beans were exported up to 100 beans per 100 grams, there are no live insects in the packaging of cocoa exported and foremost the cocoa has been fermented. Moreover, Indonesian cocoa is accused containing pesticide residues and contaminated Cadmium (Ca) (Widyastutik and Arianti, 20I2). If the requirements are not met then the prices that are received by Indonesian exporters are lower than the world price.

Germany has non-tariff barriers value for Indonesian cocoa commodities amounted to $35.979 \%$. These values indicate that the persistence of non-tariff barriers imposed by Germany for Indonesian cocoa. Likewise, Germany has a company cocoa processing in the world after the Netherlands in the EU, namely Haribo GmbH \& Co (Arista, 2012).Just like other EU countries which become Indonesian cocoa export destination, Spain processes and manufactures cocoa from Indonesia. Based on Ministry of Agriculture data, growth in volume and import value of Indonesian cocoa by Spain from 2000 to 2005 tended to be higher (Ministry of Agriculture, 2009). It is a challenge for Indonesia to improve the quality and standards of cocoa traded in Spain. Based on calculations, Spain has non-tariff barriers value of Indonesian cocoa larger than Germany that is equal to $76.510 \%$. 
Non-Tariff Barriers and Factors that influence The Indonesian

Raditya Anggoro, Widyastutik

Table 5.Indonesian Cocoa Non-Tariff Barriers

\begin{tabular}{lc}
\hline \multicolumn{1}{c}{ Country } & NTB \\
\hline France & 100 \\
Netherlands & 312.01 \\
Germany & 35979 \\
Spain & 76.510 \\
United Kingdom & 14.068 \\
Belgium & 61.406 \\
Estonia & 33.396 \\
Bulgaria & 2.079
\end{tabular}

Description: NTBs value (in percentage)

The development of cocoa industry in Belgium needs cocoa beans in large quantities. The cocoa consumption level per capita was also quite high at $9.1 \mathrm{~kg}$ per year (Arista 2012). Belgium NTBs are relatively lower than European countries that led to Indonesian cocoa exports to Belgium are relatively high. United Kingdom is also potential the EU country of Indonesian cocoa. The level of cocoa consumption per capita in the United Kingdom is at $8.8 \mathrm{~kg}$ per year (Arista, 20I2). The high level of cocoa consumption is an opportunity for Indonesia. Compared to Belgium, the United Kingdom has low of non-tariff barriers value, amounting to $14.068 \%$. This shows that United Kingdom tends to be laxer in regulating the import policy of cocoa from Indonesia while Bulgaria has non-tariff barriers value at $33.396 \%$. Estonia has the smallest non-tariff barriers value of $2.079 \%$. This is due to the efforts of the cooperation between the Indonesian government and the Estonian market expansion opportunities to provide better export (Ministry of Agriculture, 20I4).

\section{CONCLUSION}

Based on the results and discussion, Indonesian cocoa comparative advantage is quite high in the main export destination countries. Indonesian cocoa has high competitiveness in France and Germany compared to other destination countries of Indonesian cocoa exports. The result estimation using gravity model is known that GDP per capita of exporters and importers, the economic distance between exporters and importers, the country's consumer price index importers, exporters country's exchange rate against the importing countries, and tariffs has significantly influence to the Indonesian cocoa exports volume. The result of non- 
tariff barriers calculation shows that the highest of non-tariff barriers is the Netherlands.

In addition to enhancing the efforts of trade facilitation that related to the harmonization of regulatory standard and quality by export destinations, the amount of Indonesia cocoa non-tariff barriers to the EU market should be viewed positively as an effort to further enhance competitiveness. Effort to improve the standard and quality is started from up stream to downstream. The quality of cacao seeds with very high standards is required. Post-harvest processing should be in accordance with the export requirements such as the fermentation requirements. It should be cooperation between the government and the private sector to improve the availability and quality of cocoa standard infrastructure so as to ensure the quality of Indonesian cocoa exports in the export destinations.

\section{REFERENCES}

Behar, A \& J. A. Venables. (2010). Transport Costs and International Trade.Dept of Economics. Oxford: University of Oxford and CEPR.

Chalagan, B. A. \& U. Uprasen. (2008). Impact of the 5th EU Enlargement on ASEAN. Euro-Asia Centre (EAC). Ireland: Departement of Economics Kemmy Business School University of Limerick.

Depkeu. (20I3). ASEAN Free Trade Area. (downloaded on Dec 12, 20I3): http://www.tarif.depkeu.go.id/others/?hi=AFTA.

Firdaus, M. 20II. Aplikasi Ekonometrika untuk Data Panel dan Time Series (The Econometrica Application for Pane and Time Series Data). Bogor: IPB Press

Feenstra, R.C.et.al. (1998). Understanding The Home Market Effect and The Gravity Equation: The Role of Differentianted Goods. NBER Working Paper No.6804.

Indonesia Mission. (20I4). Laporan Peluang Ekspor Komoditi Kakao di Uni Eropa (The Report of Cocoa Commodity Opportunities in EU). [downloaded onFeb 13, 2014]: http://www.indonesianmission-eu.org.

Latifah BA, Ahmad S, Fajar A, Taufiq A. (20I3). Analisis Dampak Pengenaan Tarif Bea Masuk Impor Pada Produk Hortikultura: Studi Kasus Terhadap Komoditas Bawang Merah (The Impact of Import Tariff on Holtuculture Product: Case Study on Red 
Non-Tariff Barriers and Factors that influence The Indonesian

Raditya Anggoro, Widyastutik

Onion Comodities). Postgraduate Program of Management and Business.Bogor: Institut Pertanian Bogor.

Painte, RE. (2008). Analisis Pengaruh Hambatan Tarif dan Non-Tarif di Pasar Uni Eropa Terhadap Ekspor Komoditas Udang Indonesia (The Impact of Tariff and Non-Tariff Barriers in EU Market to Indonesia Shrimp Commoditie Exports). [Unpublished Thesis].Bogor:Institut Pertanian Bogor.

Park, S. C. (2002). Measuring Tariff Equivalent in Cross Border Trade in Services. KIEP Working Paper 02-15, Korea Institute for International Economic Policy.

Salvatore, D. (1997). International Economics. Jakarta: Erlangga.

Singagerda, S. I. (20I3). Analisis Aliran Investasi dan Perdagangan Pariwisata Indonesia.

(Trade Flow Analysis of Indonesia Investment and Tourism). (Unpublished Thesis). Bogor: Institut Pertanian Bogor.

Yuniarti. (2007). Analisis Determinan Perdagangan Bilateral Indonesia: Pendekatan Gravity Model (Determinants of Indonesia Bilateral Trade Analysis: Gravity Model Approach). Yogyakarta: Universitas Ahmad Dahlan.

Walsh, K. (2006). Trade in Services: Does Gravity Hold? A Gravity Model Approach to Estimating Barriers to Services. Institute for International Integration Studies (IIIS) Discussion Paper. No 183/October 2006.

Widyastutik \& R. K. Arianti (2013). Strategi Kebijakan Mutu dan Standar Produk Ekspor Dalam Meningkatkan Daya Saing: Studi Kasus Produk Ekspor Biji Kakao (The Strategy of Product Quality and Standard Policies on Increasing Export Competitiveness: A Case Study of Cocoa Beans Product Export).Journal of Management and Agribusiness. Vol.10 No. 2, pp. I8I-200. 